


\title{
Mixing failures of endodontic sealers: an in vivo biocompatibility study
}

\author{
Falhas durante espatulação de cimentos endodônticos: um estudo de biocompatibilidade in vivo
}

Carlos Roberto Emerenciano BUENO ${ }^{1}$, Gustavo Arcos LOPES ${ }^{1}$, Diego VALENTIM ${ }^{2}$, Vanessa Abreu Sanches MARQUES ${ }^{1}$, Ana Maria Veiga VASQUES ${ }^{1}$, Marina Tolomei Sandoval CURY', Gustavo SIVIERI-ARAÚJO ${ }^{1}$, Rogério de Castilho JACINTO ${ }^{1}$, Luciano Tavares Angelo CINTRA ${ }^{1}$, Eloi DEZAN- JUNIOR ${ }^{1}$

1 - Department of Endodontics - Araçatuba School of Dentistry - Univ. Estadual Paulista - UMESP - Araçatuba - SP - Brazil.

2 - Department of Endodontics - Centro Universitário do Distrito Federal - UDF - School of Dentistry - Brasilia - DF - Brazil.

\begin{abstract}
Objectives: Evaluate, in vivo, the influence of mixing failures on endodontic sealers. Material and Methods: To alveolus analysis, 80 rats were divided into Sealapex® and AH Plus ${ }^{\circledR}$ groups. Within each group, the sealer was subjected to either partial (incomplete homogenizationsimulating handling failures) or total mixing (complete homogenization) over two periods of 7 and 30 days $(\mathrm{n}=20)$. The maxillary incisor was extracted and a polyethylene tube containing the sealer was inserted. To quantify edema, 40 male rats were divided into four groups $(n=10)$. The animals received $2 \%$ Evans Blue intravenously, and either AH Plus $®$ or Sealapex $®$ was injected subcutaneously. The rats were euthanized after 3 or 6 hours and analyzed in a spectrophotometer $(630 \mathrm{\eta m})$. To analyze the subcutaneous tissue, 20 rats received polyethylene tube implants with the sealers in the dorsal area $(n=10)$, then euthanized after either 7 or 30 days, and inflammation was evaluated according to an inflammatory cells score. Results: In the alveolar 7-day group, control group presented an inflammation score 1 , while all other groups presented a score 2, except AH plus® total mix group (3). After 30 days, all groups presented a score 1 . The edemogenic test showed less edema in Sealapex $\AA$ groups $(\mathrm{p}<0.5)$. In subcutaneous 7-day period, all groups presented score 2 . In 30 days, all groups revealed score 1, except AH Plus® partial mix group (2). Conclusion: Regarding mixing of the sealers, there were no significant differences among the groups.
\end{abstract}

\section{KEYWORDS}

AH Plus; Inflammation; Materials testing; Root canal filling materials; Sealapex.

\section{RESUMO}

Objetivo: Avaliar, in vivo, a influência das falhas de espatulação de cimentos endodônticos. Material e Métodos: Para análise alveolar, 80 ratos foram divididos nos grupos Sealapex ${ }^{\circledR}$ e $A H$ Plus $®$. Em cada grupo, o cimento foi espatulado de forma parcial (homogeneização incompleta, simulando falhas) ou total (homogeneização completa) em dois períodos de 7 e 30 dias $(n=20)$. O incisivo superior foi extraído e um tubo de polietileno contendo o cimento foi inserido. Para quantificar edema, 40 ratos foram divididos em quatro grupos $(\mathrm{n}=10)$. Os animais receberam Azul de Evans $2 \%$ intravenoso, e AH Plus $®$ ou Sealapex $®$ injetados no tecido subcutâneo. Após 3 ou 6 horas foram eutanasiados e analisados em espectrofotômetro (630 ๆm). Para analisar a resposta subcutânea, 20 ratos receberam implantes de tubo de polietileno com os cimentos na região dorsal (n = 10), eutanasiados após 7 ou 30 dias, e a inflamação foi avaliada de acordo com um escore de células inflamatórias. Resultados: Na análise alveolar em 7 dias, o grupo controle apresentou escore 1 de inflamação, enquanto que todos os outros grupos apresentaram 2, com exceção do $\mathrm{AH}$ plus® espatulação total (3). Após 30 dias, todos os grupos apresentaram escore 1 . O teste edemogênico mostrou menor edema nos grupos Sealapex $\AA(p<0,5)$. No período subcutâneo de 7 dias, todos os grupos apresentaram escore 2. Em 30 dias, todos os grupos revelaram escore 1, exceto AH Plus® espatulação parcial (2). Conclusão: Não houve diferença estatística significante entre os cimentos quanto à espatulação.

\section{PALAVRAS-CHAVE}

AH Plus; Inflamação; Teste de materiais; materiais obturadores; Sealapex. 


\section{INTRODUCTION}

A mong the numerous materials used in endodontic therapy, dentists should take special care with those used in obturation, because they are inserted into the root canals and remain in close contact with the apical tissues [1], filling irregularities in the root walls and accessory canals that gutta percha cannot penetrate [2]. Although the contact area is small, dentists are always concerned that endodontic sealers cause undesirable reactions, and that they should therefore be biocompatible $[3,4]$. Calcium hydroxide, which is known for its therapeutic effects $[5,6]$, was added to endodontic sealers to enhance their biological properties. In particular, sealers that contain calcium hydroxide have antimicrobial effects, stimulate repair in the periapical tissues, and deposit mineralized apical tissue to create an apical seal $[7,8]$.

Sealapex ${ }^{\circledR}$ (SybronEndo, Glendora, CA) releases high amounts of calcium and hydroxyl ions [9-11]. It shows excellent tissue response [12] and has an antimicrobial effect against Enterococcus faecalis [13].

Another widely-used, commercially available sealer is AH Plus ${ }^{\circledR}$ (Dentsply De Trey Gmbh, Konstanz, Germany)—an epoxy resin-based sealer that features high flow, high radiopacity [14], and excellent physico-chemical and biological properties [15-20].

Importantly, changes in the base/catalyst ratio during the preparation of sealers may affect their physicochemical and biological properties, and extended mixing time improves their consistency and homogenization, increasing their working time [21].

Therefore, it is necessary to verify whether inadequate mixing and a lack of sealer homogenization interfere with the repair process. The aim of the present study was to evaluate the influence of partial and total mixing on the biological compatibility of Sealapex ${ }^{\circledR}$ and AH Plus ${ }^{\circledR}$.

\section{MATERIAL AND METHODS}

\section{Animals}

In total, 140 male Wistar rats weighing 250-300 g were used. The animals were housed in temperature-controlled rooms and received water and food ad libitum throughout the preexperimental period. The animals were cared for according to the guidelines of the Araçatuba School of Dentistry Ethical Committee, which approved the project before the beginning of the experiments.

Before any procedure, pre-anesthetic medication $(25 \mathrm{mg} / \mathrm{kg}$ xylazine and $50 \mathrm{mg} / \mathrm{kg}$ ketamine) was delivered intramuscularly.

\section{Polyethylene Tubes}

One hundred sixty polyethylene tubes with a $1.0-\mathrm{mm}$ internal diameter, 1.6- $\mathrm{mm}$ external diameter, and 3.0-mm length (Abbott Labs of Brazil, Sao Paulo, SP, Brazil) were filled with the tested materials [22].

\section{Mixing of the Sealers}

The mix was considered partial when the components were lightly mixed and the paste was not homogenous in color. Mixing was considered total when a single-colored mixture was obtained. The sealers were inserted into the tubes, and four groups were created according to which sealer and mixing technique were used: Group Sealapex® partial mix; Group Sealapex® total mix; Group AH Plus ${ }^{\circledR}$ partial mix; and Group AH Plus ${ }^{\circledR}$ total mix.

\section{Alveolus Procedure}

Eighty rats had their upper right incisor extracted using two adapted Hollembacks and adapted tweezers, as proposed by Okamoto and Russo [23]. After hemostasis, a polyethylene tube containing the tested material was inserted into the alveolus. Suturing was performed with an atraumatic needle and 4/0 silk. After either 7 or 30 days, the animals were euthanized by overdose of anesthetic. Their right jaw was separated, fixed in $10 \%$ formalin for 48 hours, demineralized in $17 \%$ EDTA solution, and embedded in paraffin. The specimens were then cut into $6-\mu \mathrm{m}$ sections and stained using hematoxylin and eosin. 
Test

\section{Immediate Response in the Edemogenic}

Forty animals were divided into four groups of 10 , each of which contained five animals for each time period evaluated ( 3 and 6 hours). After anesthesia, the animals received an intravenous injection of 2\% Evans Blue (Evans Blue; Difco Lab. Detroit, Michigan, USA) into the penile vein $(0.2 \mathrm{ml} / 100 \mathrm{~g})$. Thirty minutes after the injection, each animal received $0.2 \mathrm{ml}$ of the corresponding material in the dorsal region, and was euthanized after either 3 or 6 hours. The edema was identified by blue staining, removed, standardized using a 23-mm diameter iron mold, and immersed in 4 $\mathrm{ml}$ of formamide. The subsequent analyses were performed in a spectrophotometer (Cary 50 Bio, Varian) at a wavelength of $630 \mathrm{~nm}$. The results were analyzed using two-way analysis of variance and the Tukey test with a significance level of 5\%, performed with the Sigma Plot (version 12.0; Systat Software Inc., CA) software.

\section{Subcutaneous Implant}

Twenty Wistar rats were used across twotime periods ( 7 and 30 days). Each rat received four implants, depending on their group allocation (Sealapex® partial mix, Sealapex ${ }^{\circledR}$ total mix, AH Plus ${ }^{\circledR}$ partial mix, AH Plus ${ }^{\circledR}$ total mix). After shaving the dorsal area and disinfecting it with $5 \%$ iodine solution, a $1-\mathrm{cm}$ long longitudinal incision was made, and the tubes were inserted in opposite directions (upper right, upper left, lower right, and lower left), and the skin was closed with a 4/0 silk suture (Johnson \& Johnson Produtos Profissionais Ltda, São José dos Campos, Brazil). After the experimental time periods, the animals were euthanized using an overdose of anesthetic, and the tubes, along with the surrounding tissue, were removed and fixed in 10\% formalin. The pieces were embedded in glycol methacrylate (Leica Historesin), cut into $3-\mu \mathrm{m}$ sections, and stained using hematoxylin and eosin [24,25].

\section{Inflammatory Analysis}

Inflammatory infiltrates were observed at
$40 \times$ magnification, and the approximate number of inflammatory cells present was calculated. The absence of inflammatory cells received a score of 0 . When fewer than 25 inflammatory cells were present, inflammation was considered mild (score 1). Moderate inflammation (score 2) was assigned when 25-125 inflammatory cells were detected. Inflammatory cell counts higher than 125 were considered severe (score 3). Similarly, the thickness of the fibrous capsule was classfied as follows: considered thin when $<150 \mu \mathrm{m}$, while and considered thick when $>150 \mu \mathrm{m}[25,26]$. The data were submitted for statistical analysis using the Sigma Plot (version 12.0; Systat Software Inc., CA) software program. The Kruskal-Wallis test was performed to analyze non-parametric data. P-values $<.05$ were considered significant.

\section{RESULTS}

\section{Alveolus}

The histologic analysis is shown in Table 1 and representative images of each alveolus group is displayed in Figure $1(A-J)$. At 7 days, all groups presented moderate inflammatory infiltrate (median score 2) except $\mathrm{AH}$ Plus ${ }^{\circledR}$ Total Mix (median score 3). Newly formed vessels, indicating that angiogenesis, which is necessary for tissue repair, had taken place. The specimens also showed advanced new-bone formation, with trabecular bone around the tube and at the bottom of the alveolus. The AH Plus ${ }^{\circledR}$ Total Mix showed a lack of fibroblasts in the connective tissue showed and no bone or blood vessel formation was observed. No statistical difference was observed ( $p>0.05$ ). At 30 days, the inflammation was mild (median score 1) for all groups, with exception of AH Plus Total Mix ${ }^{\circledR}$, which presented a decrease in the inflammatory infiltrate, but most of specimens achieved a moderate inflammation (median score 2), without statistical significance ( $p>$ 0.05). Advanced bone formation was observed around the tube, connective tissue had been repaired, and several fibroblasts were present. Angiogenesis had also occurred. 


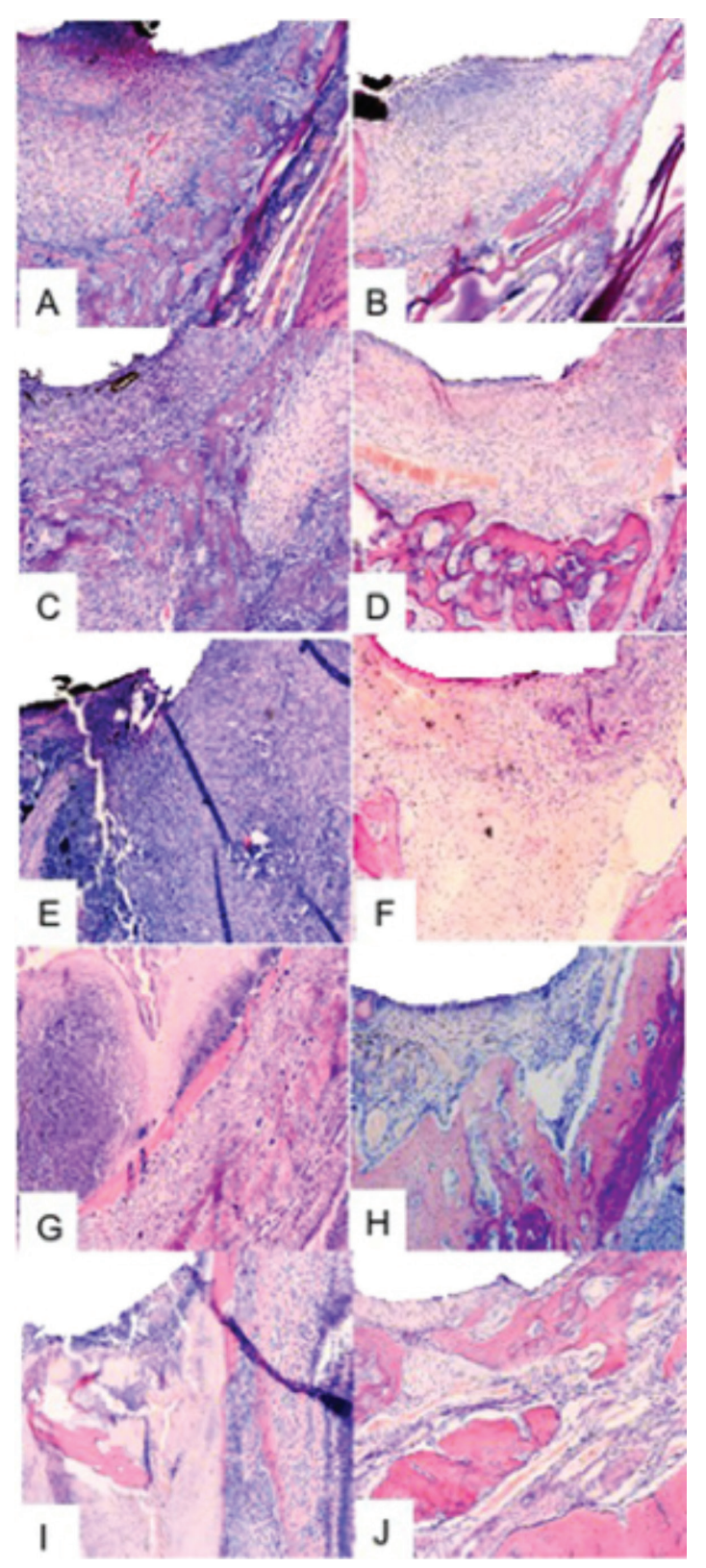

Figure 1 - Alveolar Analysis: Control Group 100x: (A) 7 days, thick fibrous capsule and mild inflammatory infiltrate; (B) 30 days, reduction of the fibrous capsule and mild inflammatory cell infiltrate. Sealapex® Partial 100x: (C) 7 days, thick fibrous capsule and infiltrate moderate inflammatory with presence of lymphocytes and macrophages; (D) 30 days, thin fibrous capsule around the tube with few chronic inflammatory cells. AH Plus ${ }^{\circledR}$ Partial 100x: (E) 7 days, moderate inflammatory infiltrated and thick fibrous capsule; (F) 30 days, thin fibrous capsule and mild inflammatory infiltrate. Sealapex® Total 100x: (G) 7 days, thick fibrous capsule and moderate inflammatory infiltrate with presence of lymphocytes and macrophages; (H) 30 days, thin fibrous capsule around the tube with few inflammatory cells; AH Plus ${ }^{\circledR}$ Total 100x: (I) 7 days, severe inflammatory infiltrate and thick fibrous capsule; (J) 30 days, thin fibrous capsule and moderate inflammatory infiltrate.
Table 1 - Percentage of samples in each alveolus group categorized according to the inflammatory score, the median and the thickness of fibrous capsule in the experimental periods.

\begin{tabular}{|c|c|c|c|c|c|}
\hline & & $\begin{array}{c}\text { Score } \\
(\%)\end{array}$ & & & Median \\
\hline 7Days & 0 & 1 & 2 & 3 & \\
\hline Control & 0 & 0 & 100 & 0 & 2 \\
\hline Sealapex Partial & 0 & 0 & 70 & 30 & 2 \\
\hline AH Plus Partial & 0 & 0 & 80 & 20 & 2 \\
\hline Sealapex Total & 0 & 0 & 90 & 10 & 2 \\
\hline AhPlus Total & 0 & 0 & 40 & 60 & 3 \\
\hline \multicolumn{6}{|l|}{30 days } \\
\hline Control & 0 & 100 & 0 & 0 & 1 \\
\hline Sealapex Partial & 0 & 80 & 20 & 0 & 1 \\
\hline AHPlus Partial & 0 & 90 & 10 & 0 & 1 \\
\hline Sealapex Total & 0 & 80 & 20 & 0 & 1 \\
\hline AhPlus Total & 0 & 40 & 60 & 0 & 2 \\
\hline
\end{tabular}

\section{EDEMOGENIC TEST}

Table 2 shows the mean and standard deviation obtained in the edema measurement. These data comprised three criteria-sealer, time, and mixing - and were thus subjected to analysis of variance.

Sealapex ${ }^{\circledR}$ caused less edema than AH Plus ${ }^{\circledR}$ ( $\mathrm{p}<0.05$ ) under both study conditions. However, neither mixing nor time had any effect ( $\mathrm{p}>0.05)$.

Table 2 - Edemogenic test results: mean and standard deviation from each experimental group

\begin{tabular}{|ccccc|} 
& $\begin{array}{c}3 \text { hours } \\
\text { SealapeX } \AA\end{array}$ & $\begin{array}{c}6 \text { hours } \\
\text { SealapeX } \AA\end{array}$ & $\begin{array}{c}3 \text { hours } \\
\text { AHPlus } \AA\end{array}$ & $\begin{array}{c}6 \text { hours } \\
\text { AHPlus } \AA\end{array}$ \\
\hline Partial Mix & $0.49 \pm 0.11$ & $0.428 \pm 0.07$ & $1.332 \pm 0.51$ & $1.305 \pm 0.40$ \\
\hline Total Mix & $0.421 \pm 0.08$ & $0.31 \pm 0.03$ & $0.865 \pm 0.20$ & $1.440 \pm 0.28$ \\
\hline
\end{tabular}

\section{SUBCUTANEOUS}

Representative images of the tissue response of each group can be observed in Figure $2(\mathrm{~A}-\mathrm{J})$, and the histologic analysis is shown in Table 3. After 7 days, polymorphonuclear and macrophages cells were observed at the opening of the tubes, achieving a median score 2 (moderate reaction) and a thick fibrous capsule in all groups, even in control group, due to the surgical trauma. Inflammatory cells were observed mainly in the partial mixing 
groups, with few specimens showing severe inflammation compared with the control and total mixing groups (moderate inflammatory infiltrate) but without statistical difference (p $>0.05$ ). After 30 days, only AH Plus ${ }^{\circledR}$ Partial Mix showed a median score 2, while all groups achieved score 1 (mild inflammation), without statistical significance $(\mathrm{p}>0.05)$. The fibrous capsule was thin for all groups but Sealapex total mixing, which presented a fibrous capsule over $150 \mu \mathrm{m}$ containing macrophages phagocytizing the extruded sealer, due to its solubility.

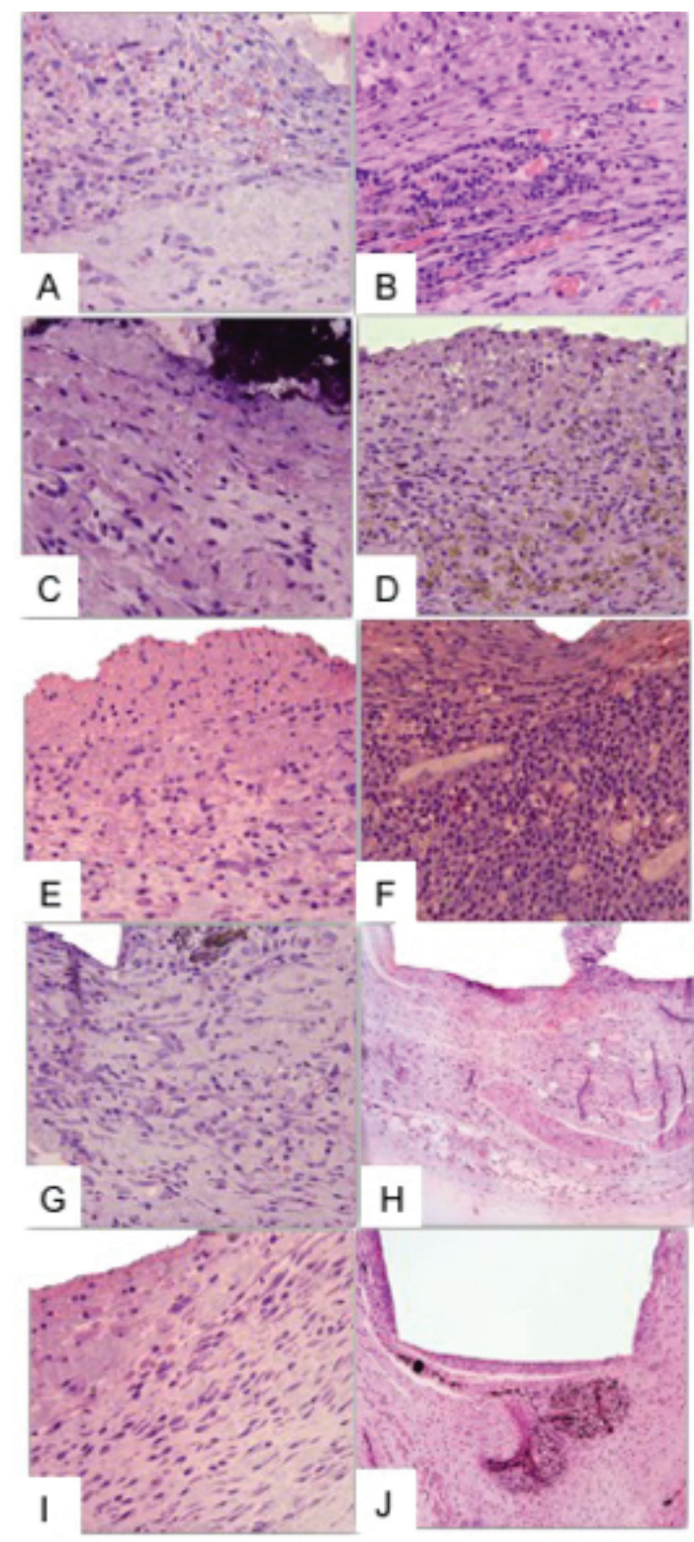

Figure 2 - Subcutaneous tissue reactions in the experimental groups. Control group: (A) thick fibrous capsule and moderate inflammatory reaction (7 days, HE, 400x); (B) reduction in the thickness of the fibrous capsule and mild inflammatory reaction (30 days, HE, 400x). Sealapex partial mix: (C) thick fibrous capsule formation and moderate inflammatory cell infiltration (7 days, HE, 400x); (D) reduction in the thickness of the fibrous capsule formation and mild inflammatory cell infiltration, consisting of macrophages (30 days, $\mathrm{HE}, 400 \mathrm{x}$ ); $\mathrm{AH}$ Plus partial mix: (E) inflammatory cells phagocyting extruded sealer. Moderate Inflammation with thick fibrous capsule (7 days HE, 400x); (F) chronic infiltration of lymphocytes and the presence of macrophages. The fibrous capsule thickness varied according to the specimen -mostly thin- presenting or not extruded sealer (30 days, HE, 400x); Sealapex total mix: (G) Mild inflammation, with a thick fibrous capsule, presenting an increase of the inflammation process only when extruded sealer was observed (7 days, HE, 400x); (H) Mild inflammation in normal specimen conditions (no extruded sealer) low number of inflammatory cells, and large amount of fibroblasts. The fibrous capsule remained thick (30 days, HE, 100x); $\mathrm{AH}$ Plus total mix: (I) Presence of moderate inflammatory infiltrate, with thick fibrous capsule (7 days, HE, 400x); (J) Inflammation was less pronounced, approaching the lower score limit and a thin fibrous capsule. Presence of phagocytosed materials was observed, but in specimens without extravasation there was no presence of macrophages (30 days, HE, 100x).

Table 3 - Percentage of samples in each group of the subcutaneous analysis, categorized according to the inflammatory score, the median and the thickness of fibrous capsule in the experimental periods

\begin{tabular}{|ccccccc|}
\hline & \multicolumn{3}{c}{$\begin{array}{c}\text { Score } \\
(\mathbf{\%})\end{array}$} & & Median & Capsule \\
\hline 7Days & $\mathbf{0}$ & $\mathbf{1}$ & $\mathbf{2}$ & $\mathbf{3}$ & & \\
\hline Control & 0 & 0 & 100 & 0 & 2 & Thick \\
\hline Sealapex Partial & 0 & 0 & 70 & 30 & 2 & Thick \\
\hline AH Plus Partial & 0 & 0 & 60 & 40 & 2 & Thick \\
\hline Sealapex Total & 0 & 0 & 80 & 20 & 2 & Thick \\
\hline AhPlus Total & 0 & 0 & 80 & 20 & 2 & Thick \\
\hline 30 days & & & & & & \\
\hline Control & 0 & 100 & 0 & 0 & 1 & Thin \\
\hline Sealapex Partial & 0 & 90 & 10 & 0 & 1 & Thin \\
\hline AHPlus Partial & 0 & 40 & 60 & 0 & 2 & Thin \\
\hline Sealapex Total & 0 & 90 & 10 & 0 & 1 & Thick \\
\hline Ah Plus Total & 0 & 90 & 10 & 0 & 1 & Thin \\
\hline & & & & & & \\
\hline
\end{tabular}

\section{DISCUSSION}

The study of dental materials biocompatibility in Wistar rats was performed because previous investigations [12,27] have indicated that alveolarimplant—a simpleinsertion 
technique that simulates the reactions of the apical tissue area-closely models the endodontic clinical condition [28]. However, the authors of these previous reports stated that any material introduced into the extraction socket disturbed tissue organization and injured the periodontal ligament, leading to delays in the normal repair process $[23,29]$. The edema that occurs almost immediately after trauma is caused by increased vascular permeability. Consequently, the passage of blood proteins increases. When administered intravenously, Evans Blue dye binds to plasma proteins (mainly albumin), allowing researchers to estimate the intensity of the edematous area [30,31].

The edemogenic test is used after obturation to analyze the initial reaction of the periapical tissues when sealers are extruded. In the present study, the edemogenic test was performed according to the method of Machado et al. [31], although it was slightly modified.

Torneck [32] was the first to use subcutaneous implants in rats to evaluate the reaction of connective tissue to implanted polyethylene tubes. The method is now a common preliminary biocompatibility test, and it is currently used in rats to verify the biocompatibility of implantation material in subcutaneous tissue $[25,26]$. In this way, researchers can evaluate the tissue response around the implants [33,34], and the test has been widely accepted for this purpose [35]. Polyethylene tubes do not induce persistent irritation, and the tested material remains in the surrounding area. Thus, they allow researchers to analyze inflammatory infiltrates $[33,34,36]$.

In the present study, we evaluated implantinduced tissue irritation according to criteria described by several authors $[25,26]$ and by the Federation Dentaire International Commission of Dental Materials, Instruments, Equipment, and Therapeutics [37]. Inflammatory infiltrates differed between the 7-day and 30-day subjects. After 7 days, all groups, including the control group, showed a thick fibrous capsule and mainly a score of 2. This finding corroborates previous studies, which have reported that polyethylene tube implantation causes surgical trauma, and that this is a standard reaction that subsides over time [22,24-26].

After 30 days there was chronic inflammatory infiltrate characterized by large amounts of macrophages, lymphocytes, and eosinophils. In addition, there were more fibroblasts, indicating that tissue repair had taken place, and new blood vessels had also formed (angiogenesis). The fibrous capsule was classified as thin in most specimens. Importantly, because Sealapex ${ }^{\circledR}$ has higher solubility, it may lead to sealer extrusion, which would elevate the presence of macrophages. In cases where the sealer had extruded, the inflammatory score was higher because there were more macrophages and fewer acute inflammatory cells; this also increased the thickness of the fibrous capsule. Interestingly, the edemogenic analysis showed less edema in the Sealapex groups $(\mathrm{p}<.05$ ), corroborating this finding.

The inflammation in the $\mathrm{AH}$ plus group was possibly caused by the resin in the sealer composition (Bisphenol-A diglycidyl ether); sealers based on epoxy resin release formaldehyde during mixing [38,39], which may provoke a more severe inflammatory reaction that reduces to a non-significant level over time.

To compare the experimental groups, the scores were submitted to the Kruskal-Wallis test. In this way, the evolution of the healing process was observed over time-from 7 to 30 days ( $p$ $<.05)$-in all materials. However, there was no difference in tissue response between the different mixing quality methods: partial or total $(p>.05)$.

\section{CONCLUSION}

In conclusion, using both the subcutaneous and alveolar methodologies, the endodontic sealers Sealapex ${ }^{\circledR}$ and $\mathrm{AH}$ Plus ${ }^{\circledR}$ showed similar biocompatibility results in the maximum 
period of 30 days. The mixing method (partial or total) regarding complete or incomplete homogenization had no influence in the sealer's biocompatibility and should not influence the clinical results.

\section{ACKNOWLEDGEMENTS}

This research was granted by FAPESP process number 2011/18545-8.

\section{REFERENCES}

1. Silveira CM, Pinto SC, Zedebski Rde A, Santos FA, Pilatti GL Biocompatibility of four root canal sealers: a histopathological evaluation in rat subcutaneous connective tissue. Braz Dent J. 2011;22(1):21-7.

2. Chhabra A, Teja TS, Jindal V, Singla MG, Warring K. Fate of Extruded Sealer: A Matter of Concern. J Oral Health Comm Dent. 2011;5(3):168-172.

3. Orstavik D. Materials used for root canal obturation: technical, biological and clinical testing. Endod Top. 2005;12:25-38.

4. Branstetter J, von Fraunhofer JA. The physical properties and sealing action of endodontic sealer cements: a review of the literature. J Endod. 1982;8(7):312-6.

5. Foreman PC, Barnes IE. A review of calcium hydroxide. Int Endod J. 1990 Nov;23(6):283-97.

6. Sjogren U, Figdor D, Spangberg L, Sundqvist G. The antimicrobial effect of calcium hydroxide as a short-term intracanal dressing. Int Endod J. 1991;24(3):119-25

7. Holland R, de Souza V. Ability of a new calcium hydroxide root canal filling material to induce hard tissue formation. J Endod. 1985;11(12):535-43

8. Desai S, Chandler N. Calcium Hydroxide-Based Root Canal Sealers: A Review. J Endod. 2009;35(4):475-80.

9. Leonardo MR, Silva LA, Utrilla LS, Assed S, Ether SS. Calcium hydroxide root canal sealers: histopathologic evaluation of apical and periapical repair after endodontic treatment. J Endod. 1997;23(7):428-32

10. Zmener 0, Cabrini RL. Effects of three calcium hydroxide-based materials on human blood monocytes and lymphocytes. Endod Dent Traumatol. 1987;3(1):28-32.

11. Duarte MA, Demarchi AC, Giaxa MH, Kuga MC, Fraga SC, de Souza LC. Evaluation of $\mathrm{pH}$ and Calcium Ion Release of Three Root Canal Sealers. J Endod. 2000;26(07):389-90.

12. Mittal M, Chandra S, Chandra S. Comparative Tissue Toxicity Evaluation of Four Endodontic Sealers. J Endod. 1995;21(12):622-4.

13. Zhang H, Shen Y, Ruse ND, Haapasalo M. Antibacterial activity of endodontic sealers by modified direct contact test against Enterococcus faecalis. J Endod. 2009;35(7):1051-5.
14. Marciano MA, Guimarães BM, Ordinola-Zapata R, Bramante CM, Cavenago BC, Garcia RB, et al. Physical Properties and Interfacial Adaptation of Three Epoxy Resin-based Sealers. J Endod. 2011 0ct;37(10):1417-21

15. Azar NG, Heidari M, Bahrami ZS, Shokri F. In vitro cytotoxicity of a new epoxy resin root canal sealer. J Endod. 2000;26(8):462-5.

16. Kopper PM, Figueiredo JA, Della Bona A, Vanni JR, Bier CA, Bopp $S$. Comparative in vivo analysis of the sealing ability of three endodontic sealers in post-prepared root canals. Int Endod J. 2003;36(12):857-63

17. McMichen FR, Pearson G, Rahbaran S, Gulabivala K. A comparative study of selected physical properties of five root-canal sealers. Int Endod J. 2003:36(9):629-35.

18. Schafer E, Zandbiglari T. Solubility of root canal sealers in water and artificial saliva. Int Endod J. 2003;36(10):660-9

19. Leonardo MR, Silva LAB, Almeida WA, Utrilla LS. Tissue response to an epoxy resin-based root canal sealer. Endod Dent Traumatol. 1999:15(1):28-32

20. Almeida JF, Gomes BP, Ferraz CC, Souza-Filho FJ, Zaia AA. Filling of artificial lateral canals and microleakage and flow of five endodontic sealers. Int Endod J. 2007;40(9):692-9.

21. Negm MM, Lilley JD, Combe EC. A study of the viscosity and working time of resin- based root canal sealers. J Endod. 1985;11(10):442-5

22. Gomes-Filho JE, Watanabe S, Bernabé PF, de Moraes Costa MT. A Mineral Trioxide Aggregate Sealer Stimulated Mineralization. J Endod. 2009;35(2):256-60.

23. Okamoto T, de Russo MC. Wound healing following tooth extraction: histochemical study in rats. Rev Fac Odontol Aracatuba. 1973;2(2):153-69.

24. Gomes-Filho JE, Gomes BPF, Zaia AA, Novaes PD, Souza Filho FJ. Glycol methacrylate: an alternative method for embedding subcutaneous implants. J Endod. 2001 Apr;27(4):266-8.

25. Bueno CRE, Valentim D, Marques VAS, Gomes-Filho JE, Cintra LTA, Jacinto RC, Dezan-Junior E. Biocompatibility and biomineralization assessment of bioceramic-, epoxy-, and calcium hydroxidebased sealers. Braz Oral Res. 2016 Jun 14;30(1). pii: S180683242016000100267. doi: 10.1590/1807-3107BOR-2016.vol30.0081.

26. Cintra LTA, Ribeiro TAAR, Gomes-Filho JE, Bernabé PF, Watanabe $S$, Facundo AC et al. Biocompatibility and biomineralization assessment of a new root canal sealer and root-end filling material. Dent Traumatol. 2013;29(2):145-50.

27. Olsson B, Sliwkowski A, Langeland K. Subctaneous implantation for the biological evaluation of endodontic materials. J Endod. 1981;7(8):355-67.

28. DeGrood ME, Oguntebi BR, Cunningham CJ, Pink R. A comparison of tissue reactions to Ketac-Fil and Amalgam. J Endod. 1995;21(2):65-9.

29. Rosa AL, Brentegani LG, Grandini SA. Hydroxylapatite and tricalcium phosphate implants in the dental alveolus of rats: a histometric study. Braz Dent J. 1995;6(2):103-9. 
30. Rutberg M, Spangberg E, Spangberg L. Evaluation of enhanced vascular permeability of endodontic medicaments in vivo. J Endod. 1977 Sep;3(9):347-51.

31. Machado AC, Dezan-Junior E, Gomes-Filho JE, Cintra LT, Ruviére DB, Zoccal R. Evaluation of tissue reaction to Aroeira (Myracrodruon urundeuva) extracts: a histologic and edemogenic study. J Appl Oral Sci. 2012;20(4):414-8.

32. Torneck CD. Reaction of rat connective tissue to polyethylene tube implants part I. Oral Surg Oral Med Oral Pathol. 1966;21(3):379-87.

33. Zmener 0 , Guglielmotti MB, Cabrini RL. Biocompatibility of two calcium hydroxide-based endodontic sealers: a quantitative study in the subcutaneous connective tissue of the rat. J Endod. 1988;14(5):229-35.

34. Economides N, Kotsaki-Kovatsi VP, Poulopoulos A, Kolokuris I, Rozos G, Shore R. Experimental Study of the biocompatibility offour root canal sealers and their influence on the zinc and calcium content of several tissues. J Endod. 1995;21(3):122-7.
35. Stanford JW. Recommended standard practices for biological evaluation of dental materials. Int Endod J. 1980;30:140-88.

36. Spangberg L. Biologic effects of root filling materials. Experimental investigation of the toxicity of root canal filling materials "in vitro" and "in vivo". Odontol Revy. 1969;20:5-32

37. Recommended standard practices for biological evaluation of dental materials. Federation Dentaire International Commission of Dental Materials, Instruments, Equipment and Therapeutics. Int Dent J. 1980;30(2):140-88.

38. Schweikl H, Schmalz G, Federlin M. Mutagenicity of root canal sealer AH-Plus in Ames test. Clin Oral Invest. 1998;2:125-9.

39. Neto KO, Moura AAM, Davidowicz H. Comparative study of rat's connective tissue reaction, against three endodontic resin cements. J Health Sci Inst. 2010;28(1):67-70.

\section{Eloi Dezan Junior}

\section{(Corresponding address)}

Araçatuba School of Dentstry, Univ. Estadual Paulista

(UNESP)

Department of Endodontics, R. José Bonifácio, 1193,

16015-050, Araçatuba/São Paulo, Brazil.

Tel number: +55.18.3636.3254,

Fax number: +55.18 .3636 .3236$

Date submitted: 2017 Sep 13

E-mail address: dezan@foa.unesp.br 